\title{
STRUKTUR KOMUNITAS MAKROALGA PADA SUBSTRAT YANG BERBEDA DI PERAIRAN WANDOKA, KECAMATAN WANGI-WANGI KABUPATEN WAKATOBI
}

\section{Community Structure of Macroalgae on Different Substrate in Wandoka Waters Wangi-Wangi Sub-District Wakatobi District}

\author{
Yusriana $^{1}$, Wa Nurgayah ${ }^{2}$, Ira $^{3}$ \\ ${ }^{1}$ Mahasiswa Jurusan Ilmu Kelautan, \\ Fakultas Perikanan dan Ilmu Kelautan, Universitas Halu Oleo. \\ Jl. H.E.A Mokodompit Kampus Hijau Bumi Tridharma Anduonohu Kendari 93232, Telp/Fax: (0401) 3193782 \\ ${ }^{2}$ Surel: nurgayah_fish@yahoo.com \\ ${ }^{3}$ Surel: bahari_00@yahoo.co.id
}

\begin{abstract}
Abstrak
Makroalga merupakan kelompok tumbuhan yang tidak memiliki akar, batang, bunga dan daun sejati. Makroalga termasuk tumbuhan yang bernilai ekonomis dan memiliki peranan penting secara ekologis. Penelitian ini dilaksanakan pada bulan April-Agustus 2019, dengan tujuan untuk mengetahui struktur komunitas makroalga pada substrat yang berbeda. Pengambilan data dilakukan dengan menggunakan metode transek garis, dengan jarak $50 \mathrm{~m}$. Masing-masing transek garis disimpankan transek kuadrat $(1 \times 1 \mathrm{~m})$ dengan jarak ukuran kuadran $10 \mathrm{~m}$. Pengambilan data di setiap stasiunnya dilakukan sebanyak 3 sub stasiun, dengan interval $20 \mathrm{~m}$. Jenis makroalga yang didapatkan pada lokasi penelitian yaitu 20 jenis yang terdiri dari 8 jenis Chlorophyta, 7 jenis Rhodophyta dan 5 jenis Phaeophyta. Komposis jenis tertinggi terdapat pada stasiun III dari jenis Dicthyota dichotoma dengan presentase 59\%. Kepadatan makroalga berkisar antara 21,667-32,056 ind/ $\mathrm{m}^{2}$, indeks keanekaragaman (H') berkisar antara 1,121- 2,169, indeks keseragaman (E) berkisar antara 0,626-0,905 dan Dominansi (D) berkisar antara 0,130-0,424.
\end{abstract}

Kata kunci: struktur komunitas, makroalga, substrat, Wandoka

\section{Abstract}

Macroalgae is a group of plants that do not have true roots, stems, flowers and leaves. Macroalgae has economic value and plays an important roleecologically. The purpose of this study was to determine the structure communities of macroalgae on different substratesin Wandoka Waters, Wangi-Wangi of Wakatobi. A $50 \mathrm{~m}$ of line transect was used to collect data. Quadrant transect with $1 \times 1 \mathrm{~m}$ with intervals $10 \mathrm{~m}$ was placed along the line transect. Each station consisted of three sub stations with intervals $20 \mathrm{~m}$. A total of 20 types of macroalgae was found at the study site consisting of 8 types of Chlorophyta, 7 types of Rhodophyta and 5 types of Phaeophyta. The highest type of composition was found in station III i.e Dicthyota dichotoma achieved 59\%. The highest density of macroalgae was found at sand substrate while the lowest was found at coral reef substrate. Species diversity was in medium category with a high uniformity and with a low dominance.

Kata kunci: community structure, macroalgae, substrate and Wandoka

\section{Pendahuluan}

Kawasan pesisir dan laut di Indonesia memegang peranan penting, dimana kawasan ini memiliki nilai strategis berupa potensi sumberdaya alam dan jasa-jasa lingkungan yang disebut sumberdaya pesisir. Indonesia mempunyai perairan laut yang lebih luas dari daratan, oleh karena itu Indonesia dikenal sebagai negara maritim. Perairan laut Indonesia kaya akan berbagai biota laut baik flora maupun fauna yang memiliki nilai potensial dan memiliki peranan penting secara ekologi dan ekonomi. Makroalga termasuk bagian dari flora yang terdiri atas banyak jenis dan memiliki peranan penting pada lingkungan laut (Palallo, 2013).
Makroalga merupakan alga laut dari marga-marga tertentu dikelompokan dengan nama rumput laut dan dipanen sebagai bahan pangan, sebagai sumber obat-obatan, sebagai sumber bahan kimia untuk industri dan sebagai pupuk pertanian (Romimohtarto dan Juwana, 1999). Beberapa manfaat dari alga yang sering disebutkan adalah sebagai bahan dasar berbagai industri utamanya industri makanan, obat-obatan, tekstil, kecantikan dan farmasi, serta berbagai industri lainnya bahkan saat ini sedang terus dikaji manfaat alga untuk bioethanol atau biogas (Kasim, 2016). Jenis makroalga yang termaksud dalam kelompok bahan obat, yaitu kelas 
Chlorophyceae dari marga Halimeda untuk antibakteri, kelas Phaeohpyceae dari marga Padina untuk antibakteri, dan dari kelas Rhodophyceae dari marga Corallina untuk obat pembiusan dan antibakteri (Dawes, 1981).

Rumput laut adalah salah satu tumbuhan laut yang hidup di perairan pantai dangkal dengan substrat dasar berupa pasir, pasir bercampur lumpur, karang mati maupun pecahan karang (Papalia dan Arfah, 2013). Keberadaan makroalga sebagai organisme laut banyak sekali memberikan manfaat bagi kehidupan akuatik terutama bagi organismeorganisme herbivora perairan laut maupun sebagai penyedia karbonat di perairan laut (Nyabakken, 1992).

Struktur komunitas adalah gambaran umum mengenai suatu komunitas yang mencangkup karakteristiknya yang meliputi komposisi jenis, dominansi jenis dan indeks keanekaragaman jenis. Sukiman $d k k$., (2014) menyatakan bahwa komunitas alga laut merupakan kumpulan dari beberapa jenis alga yang menempati habitat tertentu. Populasi alga tersebut terdiri atas beberapa jenis alga yang saling berinteraksi dan berasosiasi dengan organisme di sekitar habitatnya (Setiawan, 2006).

Perairan Wandoka merupakan salah satu perairan yang ada di Kecamatan Wangiwangi, Kabupaten Wakatobi. Perairan ini memiliki keanekaragaman jenis makroalga yang tersebar pada salah satu habitat yang ada di Perairan Wandoka yang memiliki substrat berpasir, substrat pecahan karang (rubble) dan substrat karang yang belum teridentifikasi jenisnya dan belum pernah dilakukan penelitian tentang makroalga di Perairan Wandoka. Berdasarkan latar belakang di atas maka perlu dilakukan penelitian mengenai Struktur Komunitas Makroalga pada Substrat yang Berbeda pada Perairan Wandoka, Kecamatan Wangi-Wangi, Kabupaten Wakatobi.

Penelitian ini bertujuan untuk mengetahui Struktur Komunitas Makroalga pada Substrat yang Berbeda di Perairan Wandoka, Kecamatan Wangi-wangi Kabupaten Wakatobi. Manfaat melakukan penelitian ini adalah sebagai data awal dan referensi mengenai struktur komunitas makroalga serta sebagai bahan pembanding bagi peneliti selanjutnya.

\section{Bahan dan Metode}

Penelitian ini telah dilaksanakan pada bulan April-Agustus 2019, yang meliputi pengambilan data dan pengolahan data penelitian. Lokasi pengambilan sampel dan data penelitian di Perairan Wandoka, Kecamatan Wangi-wangi, Kabupaten Wakatobi, Provinsi Sulawesi Tenggara. Analisis sampel substrat dilaksanakan di Laboratorium Mekanika Tanah, Fakultas Teknik, Universitas Halu Oleo.

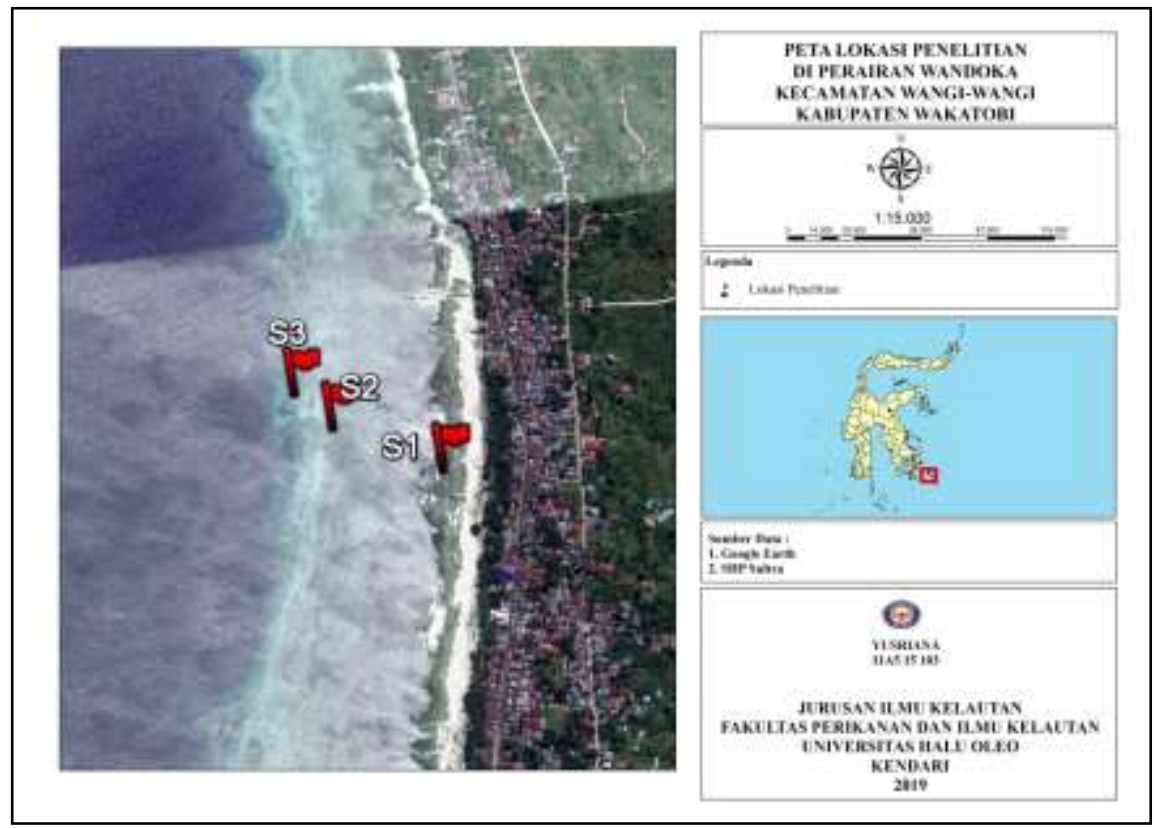

Gambar 1. Peta lokasi penelitian di Perairan Wandoka Kecamatan Wangi-wangi 
Tabel 1. Lokasi pengambilan data dan titik koordinat

\begin{tabular}{|c|c|c|}
\hline Lokasi Sampling & Koordinat & Keterangan \\
\hline Stasiun 1 & $\begin{array}{r}5^{0} 18^{\prime} 4.48^{\prime \prime} \mathrm{LS} \\
123^{0} 31^{\prime} 36.45^{\prime \prime} \mathrm{BT}\end{array}$ & $\begin{array}{l}\text { Daerah yang terletak di bagian } \\
\text { Selatan Perairan } \\
\text { substrat berpasir }\end{array}$ \\
\hline Stasiun 2 & $\begin{array}{r}5^{0} 17^{\prime} 58.87 \text { ' LS } \\
123^{0} 31^{\prime} 36.45^{\prime \prime} \mathrm{BT}\end{array}$ & $\begin{array}{l}\text { Daerah yang terletak di bagian Utara } \\
\text { Perairan Wandoka memiliki substrat } \\
\text { pecahan karang dan pasir }\end{array}$ \\
\hline Stasiun 3 & $\begin{array}{r}5^{0} 17^{\prime} 49.75^{\prime \prime} \mathrm{LS} \\
123^{0} 31 \text { '29.91" BT }\end{array}$ & $\begin{array}{lcc}\text { Daerah yang } & \text { terletak } & \text { di bagian } \\
\text { Barat Perairan } & \text { Wandoka } & \text { memiliki } \\
\text { substrat karang } & & \\
\end{array}$ \\
\hline
\end{tabular}

Pengambilan sampel makroalga dilakukan pada setiap stasiun pengamatan, diperoleh dengan menggunakan metode transek garis (Fachrul, 2007). Transek garis yang dibentangkan tegak lurus pantai. Dengan jarak $50 \mathrm{~m}$, sesuai dengan keberadaan makroalga. Masing-masing garis transek diletakan transek kuadrat (1 x $1 \mathrm{~m})$ dengan jarak ukur kuadran $10 \mathrm{~m}$ dengan cara zigzag atau (selang seling). Pengambilan data di setiap stasiunnya dilakukan sebanyak 3 sub stasiun.

Sampel makroalga yang terdapat di dalam transek dihitung jumlah perjenisnya kemudian didokumentasikan dengan menggunakan kamera digital dan makroalga yang tidak dapat diidentifikasi dimasukan ke dalam plastik sampel dan diidentifikasi sesuai dengan panduan Jha et al. (2009), Setyobudiandi et al. (2009) dan www.algabase.org. Sketsa pengambilan data makroalga dapat dilihat pada Gambar 2.

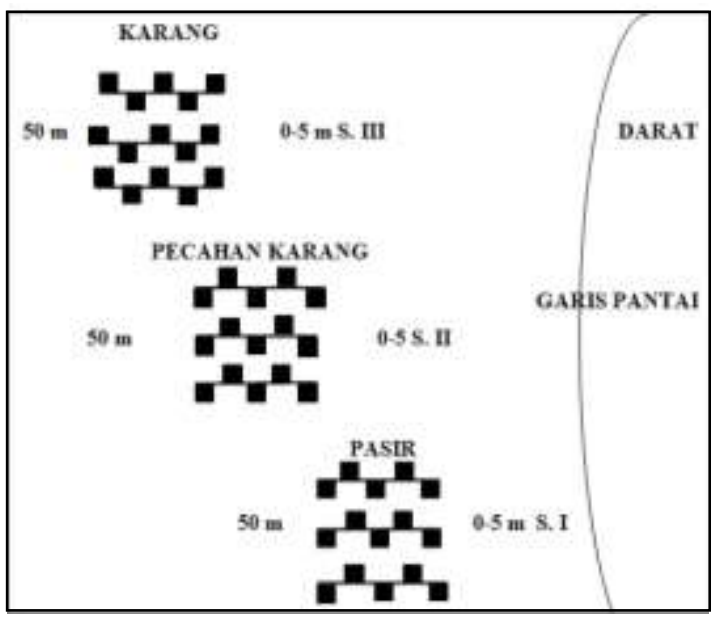

Gambar 2. Sketsa Pengambilan Sampel Makroalga

Adapun parameter lingkungan yang menjadi pengamatan dalam penelitian ini meliputi suhu, kecerahan, salinitas kecepatan arus, kedalaman perairan dan $\mathrm{pH}$.

Pengambilan sampel substrat diambil dari masing-masing transek disetiap stasiun penelitian dengan menggunakan pipa paralon ukuran 2 inci, dengan panjang $30 \mathrm{~cm}$ yang diruncingkan pada salah satu bagian ujungnya. Sampel substrat yang telah diambil dari masing-masing transek di setiap stasiun kemudian dimasukan ke dalam plastik sampel yang telah diberi label.

Komposisi jenis makroalga dihitung menggunakan persamaan (1) menurut Odum (1996):

$\mathrm{Pi}=\frac{\mathrm{ni}}{\mathrm{N}} 100 \%$

Keterangan:

$\mathrm{Pi}=$ Presentase tiap jenis $(\%)$,

$\mathrm{ni}=$ Jumlah individu spesies ke-i,

$\mathrm{N}=$ Jumlah total individu

Kepadatan makroalga dihitung dengan menggunakan persamaan (2) menurut Odum (1996) sebagai berikut :

$\mathrm{Di}=\frac{\mathrm{ni}}{\mathrm{A}}$

Keterangan :

$\mathrm{Di}=$ Kepadatan jenis (ind $/ \mathrm{m} 2$ )

ni $=$ Jumlah total individu

$\mathrm{A}=$ Luas daerah yang di sampling $\left(\mathrm{m}^{2}\right)$

Indeks keanekaragaman menunjukan ketidaktentuan yang terdapat pada spesies yang menggambarkan struktur komunitas. Semakin tinggi jumlah spesies maka semakin tinggi ketidaktentuannya. Indeks shannon $\left(\mathrm{H}^{\prime}\right)$ adalah indeks keanekaragaman yang paling populer digunakan. Kriteria nilai dalam indeks ini dibagi menjadi 3 yaitu; $\mathrm{H}<1$, Artinya keragaman jenis rendah, komunitas tidak stabil, tekanan lingkungan terhadap komunitas tinggi; $1<\mathrm{H}^{\prime}<3$ artinya keragaman jenis sedang, komunitas cukup stabil, tekanan lingkungan terhadap komunitas sedang, ada daya dukung 
lingkungan terhadap komunitas cukup ; dan jika $\mathrm{H}^{\prime}>3$ artinya keragaman jenis tinggi, komunitas stabil, kompetisi sangat rendah, daya dukung lingkungan terhadap komunitas sangat baik dan terjadi keseimbangan ekosistem (Odum, 1996).

$\mathrm{H}^{\prime}=-\sum \quad \mathrm{Pi} \operatorname{Ln} \mathrm{Pi} ; \mathrm{Pi}=$ ni/N

Keterangan:

$\mathrm{H}^{\prime}=$ Indeks keanekaragaman

$\mathrm{Pi}=$ Perbandingan total antara jumlah individu jenis ke-i dengan jumlah total individu $\mathrm{ni}=$ Jumlah

individu jenis ke-i

$\mathrm{N}=$ Jumlah total individu

Nilai indeks Keanekaragaman

Shannanon-Weiner mempunyai kisaran

Kisaran nilai tertentu yaitu sebagai berikut

$\mathrm{H}^{\prime}<1=$ Keanekaragaman rendah

$1<\mathrm{H}^{\prime}<3=$ Keanekaragaman sedang

H'>3 = Keanekaragaman tinggi

Untuk mengetahui keseimbangan komunitas digunakan menjadi indeks keseragaman yaitu ukuran kesamaan jumlah individu antara spesies dalam suatu komunitas. Semakin mirip jumlah individu antar spesies (semakin merata penyebarannya) maka semakin besar derajat keseimbangan. Keseragaman jenis dihitung dengan menggunakan persamaan (4) menurut Odum (1993) sebagai berikut.

$\mathrm{E}=\frac{H^{\prime}}{H \max }$

Keterangan :

$\mathrm{E}=$ Indeks keseragaman

$\mathrm{H}^{\prime}=$ Indeks keanekaragaman jenis

$\mathrm{H}_{\max }=$ Keanekaragaman spesies maksimum (In S)

Nilai indeks keseragaman jenis mempunyai kisaran nilai tertentu yaitu sebagai berikut:

$\mathrm{E}<0,4=$ Tingkat keseragaman populasi kecil

$0,4<\mathrm{E}<0,6=$ Tingkat keseragaman populasi sedang

E $>0,6=$ Tingkat keseragaman populasi besar

Odum (1993) menyatakan indeks keseragaman berkisar antara 0-1. Apabila nilai $\mathrm{E}$ mendekati 1 maka sebaran individu antar jenis merata. Apabila sebaran individu antar jenis tidak merata atau ada sekelompok jenis tertentu yang dominan. Semakin kecil nilai indeks keanekaragaman $\left(\mathrm{H}^{\prime}\right)$ maka indeks keseragaman (E) juga akan semakin kecil yang mengisyaratkan adanya dominansi suatu spesies terhadap spesies lain (Insafitri, 2010).

Indeks dominansi menunjukkan adanya satu atau lebih spesies yang mempunyai peranan yang jauh lebih besar terhadap komunitas dan lingkungan. Nilai indeks dominansi Simpson (D) berkisar 0-1, semakin mendekati 1 artinya semakin besar peranan/dominansi suatu jenis dalam komunitas (Odum, 1993). Indeks dominansi alga dihitung dengan persamaan:

$\mathrm{D}=\sum(\mathrm{ni} / \mathrm{N})^{2}$

Keterangan:

$\mathrm{D}=$ Indeks dominansi,

ni $=$ Jumlah individu spesies ke-i,

$\mathrm{N}=$ Jumlah total spesies

Nilai indeks dominansi jenis (D) mempunyai nilai kisaran antara 0-1. Apabila nilai $D$ semakin mendekati nilai 1 berarti semakin tinggi nilai dominansi oleh spesies tersebut. Adapun kriteria dari indeks dominansi jenis yaitu sebagai berikut:

$0,0<\mathrm{D}<0,50=$ Dominansi jenis rendah

$0,50<\mathrm{D}<0,75=$ Dominansi jenis sedang

$0,75<\mathrm{D}<1,0=$ Dominansi jenis tinggi

Frekuensi adalah peluang suatu jenis ditemukan dalam titik sampel yang diamati. frekuensi jenis makroalga dihitung dengan menggunakan persamaan (6) menurut Odum (1993) sebagai berikut :

$\mathrm{Fi}=\frac{\mathrm{Pi}}{\sum \mathrm{P}}$

Keterangan:

$\mathrm{Fi}=$ Frekuensi spesies ke-i,

$\mathrm{Pi}=$ Jumlah petak sampel ditemukan jenis ke-i,

$\Sigma \mathrm{P}=$ Jumlah total petak sampel yangdiamati.

Analisis butiran substrat dilakukan dengan metode saringan bertingkat menggunakan skala wenworth (Hubarat dan Evans, 2000).

Tabel 2. Skala Wenworth Klasifikasi Butiran Partikel-partikel Sedimen (Hutabarat dan Evans, 2000).

\begin{tabular}{cc}
\hline Ukuran $(\mathbf{m m})$ & Keterangan \\
\hline$>256$ & Kerakal \\
$2-256$ & Kerikil \\
$1-2$ & Pasir Sangat Kasar \\
$0,5-1$ & Pasir Kasar \\
$0,25-1$ & Pasir Agak Kasar \\
$0,125-0,25$ & Pasir halus \\
$0,0625-0,125$ & Pasir sangat Halus \\
$0,0039-0,00625$ & Lanau \\
$>0,0039$ & Lempung \\
\hline
\end{tabular}




\section{Hasil dan Pembahasan}

Berdasarkan hasil penelitian makroalga yang ditemukan pada perairan Wandoka sebanyak 16 family yang terdiri dari 20 jenis makroalga. Komposisi jenis makroalga paling tinggi pada stasiun I terdapat pada kelas Chlorophyta yaitu jenis $H$. opuntia dengan jumlah presentase sebesar $25 \%$. Hal tersebut dikarenakan jenis $H$. opuntia memiliki toleransi yang baik terhadap faktor lingkungan. Hal ini sesuai dengan pernyataan Arfah dan Patty (2016) yang menyatakan bahwa, marga Halimeda memiliki toleransi yang tinggi terhadap kekeringan pada waktu air laut surut terendah. Hal ini diperkuat oleh penyataan Kadi (2004), bahwa di substrat paparan terumbu yang relatif dekat dengan bagian daratan pada waktu air surut terendah makroalga yang dapat tumbuh memperlihatkan toleransi yang tinggi terhadap kekeringan terutama marga Halimeda, Padina, Gracilaria dan Sargassum. Hal ini didukung oleh penyataan
Nurkiama dkk., (2015) yang menyatakan bahwa pola sebaran makroalga kelas Chlorophyta dengan jenis Claulepa sp., H. moccoloba, H. opuntia, C. Cuptessoides dijumpai hidup di laut dan tumbuh di dasar perairan dan melekat pada jenis substrat batuan maupun pasir serta pecahan karang. Hal ini diperkuat oleh penyataan Sukiman $d k k$., (2014) yang menyatakan bahwa, lokasi dengan habitat pasir kebanyakan ditumbuhi oleh alga hijau terutama Halimeda. Halimeda merupakan jenis alga hijau yang memiliki thallus berkapur.

Komposisi jenis makroalga yang terendah pada stasiun I terdapat pada jenis $U$. fasciata dengan jumlah presentase $1 \%$. Hal ini dikarenakan $U$. fasciata senang pada habitat karang yang hidupnya melekat pada substrat berbatu. Hal ini sesuai dengan pernyataan Setyobudiandi $d k k$., (2009) yang menyatakan bahwa $U$. fasciata umumnya tumbuh di daerah rataan terumbu karang melekat pada substrat batu.

Tabel 3. Jenis Makroalga yang Ditemukan pada Perairan Wandoka.

\begin{tabular}{|c|c|c|c|c|}
\hline Stasiun & Kelas & Family & Genus & Spesies \\
\hline \multirow[t]{9}{*}{ I } & Rhodophyta & Gracilariaceae & Gracilaria & Gracilaria salicornia \\
\hline & & Hypneaceae & Hypnea & Hypnea spinella \\
\hline & Chlorophyta & Boergeneseniaceae & Boergesenia & Boergesenia forbessi \\
\hline & & Ulfaceae & Ulva & Ulfa fasciata \\
\hline & & Enteromorphaceae & Enteromorpha & Enteromorpha flexuosa \\
\hline & & Codiaceae & Halimeda & Halimeda opuntia \\
\hline & & Codiaceae & Halimeda & Halimeda tuna \\
\hline & & Chaetomorpha & Chaetomorpha & Chaetomorpha spiralis \\
\hline & Phaeophyta & Dictyutaceae & Padina & Padina australis \\
\hline \multirow[t]{10}{*}{ II } & Rhodophyta & Gracilariaceae & Gracilaria & Gracilaria coronopifolia \\
\hline & & Gracilariaceae & Gracilaria & Gracilaria salicornia \\
\hline & & Solieriaceae & Eucheuma & Eucheuma denticulatum \\
\hline & Chlorophyta & Codiaceae & Halimeda & Halimeda opuntia \\
\hline & & Codiaceae & Halimeda & Halimeda morcoloba \\
\hline & Phaeophyta & Dictyosphaeriacea & Dictyota & Dictyota dichotoma \\
\hline & & Dictyutaceae & Padina & Padina australis \\
\hline & & Phaeophytaceae & Hydroclathrus & Hydroclathrus clathratus \\
\hline & & Sargassaceae & Sargassum & Sargassum polycystum \\
\hline & & Sargassaceae & Turbinaria & Turbinaria ornata \\
\hline \multirow[t]{6}{*}{ III } & Rhodophyta & Gracilariaceae & Gracilaria & Gracilaria salicornia \\
\hline & & Chaetangiaceae & Galaxaura & Galaxaura fastigiata \\
\hline & & Coralliaceae & Amphiroa & Amphiroa flagilissima \\
\hline & Chlorophyta & Dictyosphaeriacea & Dictyosphaeria & Dictyosphaeria cavernosa \\
\hline & Phaeophyta & Dictyotaceae & Dictyota & Dictyota dichotoma \\
\hline & & Sargassaceae & Turbinaria & Turbinaria ornata \\
\hline
\end{tabular}




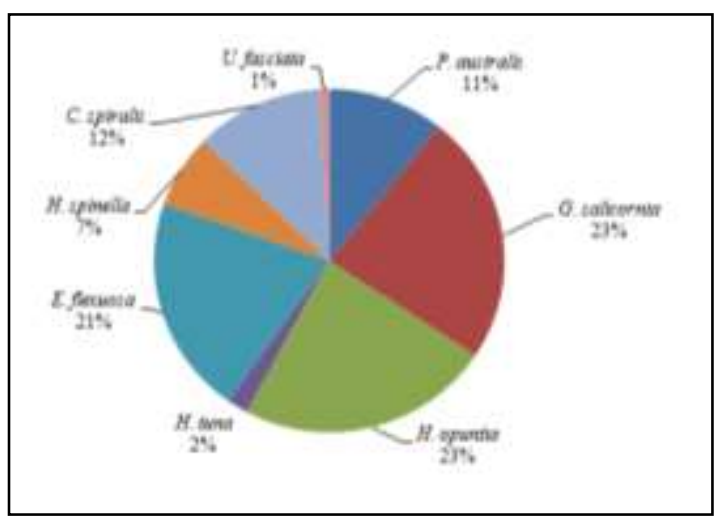

Gambar 3. Komposisi Jenis Makroalga pada Stasiun I

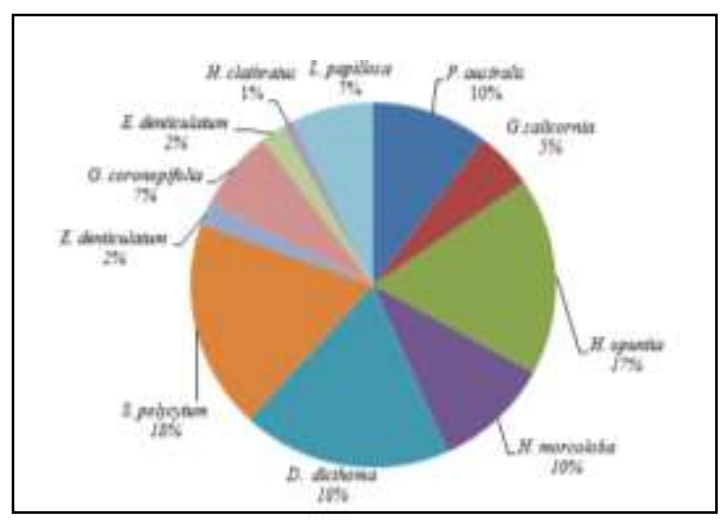

Gambar 4. Komposisi Jenis Makroalga pada Stasiun II

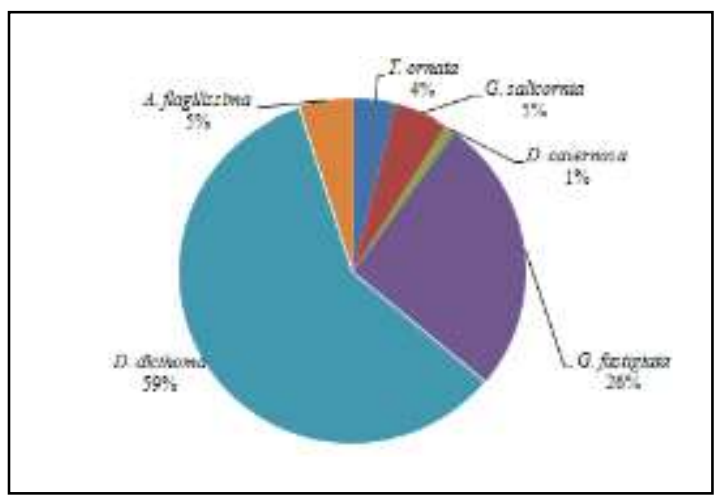

Gambar 5. Komposisi Jenis Makroalga pada Stasiun III

Komposisi jenis makroalga yang tertinggi pada stasiun II dan III terdapat pada kelas Phaeophyta. Stasiun II Komposisi jenis tertinggi terdapat pada berada pada jenis $D$. dichotoma dan $S$. polycytum dengan presentase sebesar $18 \%$. Sedangkan pada stasiun III 59\% dari jenis $D$. dichotoma. Hal ini sesuai dengan pernyataan Marianingsih (2013), bahwa jenis makroalga yang banyak dijumpai pada substrat yang keras yaitu dari divisi Phaeophyta dikarenakan jenis dari divisi Phaeophyta memiliki toleransi yang baik terhadap ombak yang terdapat di daerah pasang surut. Jenis makroalga yang umumnya tahan terhadap ombak akan dapat tumbuh dengan baik, contohnya makroalga dari Divisi Phaeophyta (Sargassum, Turbinaria, Padina). Berdasarkan hasil penelitian Ariani (2016) yang menyatakan bahwa, pada substrat berbatu komposisi makroalga yang ditemukan beragam dengan komposisi terbanyak terdapat pada kelas phaeophyta dengan persentase sebesar $45 \%$ dari jenis $P$. australis, $S$. polycystum, $D$. dichotoma, dan $P$. minor. Banyaknya jenis dari phaeophyta disebabkan karna organisme kelas ini menyukai substrat batu karang.

Komposisi jenis makroalga yang terendah pada stasiun II dan stasiun III yaitu jenis $H$. claratus dan $D$. cavernosa dengan presentase $1 \%$. Hal ini dikarenakan kedua jenis makroalga ini hanya didapatkan pada substrat tertentu. Hal ini sesuai dengan pernyataan marian $d k k$., (2016) yang menyatakan bahwa, makroalga jenis $D$. cavernosa hanya ada pada habitat batuan. Menurut Setyobudiandi dkk., (2009) $H$. claratus tumbuh melekat pada substrat berbatu.

Berdasarkan hasil penelitian makroalga di Perairan Wandoka diperoleh 20 jenis makroalga dan termasuk dalam kategori tinggi bila dibadingkan dengan hasil penelitian Ariani (2016) di Perairan Lalowaru diperoleh 16 jenis makroalga, Rosdiana (2017) di Perairan Wawora diperoleh 10 jenis makroalga, Ira (2018) di Perairan Mata diperoleh 17 jenis makroalga dan Nurlela (2018) di Perairan Langgara Bajo di peroleh 18 jenis makroalga. Hal ini dipengaruhi oleh kondisi substrat yang ada pada setiap lokasi penelitian dan kondisi habitat. Hal ini sesuai dengan pernyataan Kadi (2000) yang menyatakan bahwa, kehadiran jenis-jenis rumput laut menunjukkan bahwa kombinasi struktur substrat sangat menentukan variasi jenis rumput laut. Di pantai dengan struktur substrat yang hampir sama keanekaragaman jenisnya mendekati kesamaan. Menurut Soegiarto dkk., (2011), bahwa hasil penelitian menunjukan masing-masing lokasi memiliki kepadatan spesies yang berbeda. Hal ini diduga berkaitan dengan kondisi tipe substrat, kecerahan dan sirkulassi kecepatan arus dikaitkan dengan nutrien, adaptasi makroalga dengan lingkungan itu sendiri. 
Tabel 4. Struktur Komunitas makroalga pada setiap stasiun pada Lokasi Penelitian

\begin{tabular}{lccc}
\hline \multirow{2}{*}{ Struktur Komunita Makroalga } & \multicolumn{3}{c}{ Stasiun } \\
\cline { 2 - 4 } & I & II & III \\
\hline Kepadatan & 32,056 & 25,611 & 21,667 \\
Keanekaragaman (H') & 1,910 & 2,169 & 1,121 \\
Keseragaman (E') & 0,897 & 0,905 & 0.626 \\
Dominansi (D) & 0,163 & 0,130 & 0,424 \\
\hline
\end{tabular}

Tabel 5. Analisis Frekuensi Kemunculan

\begin{tabular}{clcccc}
\hline \multirow{2}{*}{ No } & \multicolumn{1}{c}{ Jenis Makroalga } & I & II & III & $\begin{array}{c}\text { Frekuensi } \\
\text { kemunculan(\%) }\end{array}$ \\
\cline { 3 - 6 } 1 & Rhodophyta (Alga Merah) & & & & \\
2 & Gracilaria coronopifolia & - & 4 & - & 4 \\
3 & Gracilaria salicornia & 7 & 3 & 1 & 11 \\
4 & Eypnea spinella & 4 & - & - & 4 \\
5 & Laurencia papallosa & - & 2 & - & 2 \\
6 & Galaxaura fastigiata & - & 5 & - & 5 \\
7 & Amphiroa flagilissima & - & - & 4 & 4 \\
\hline & Chlorophyta (Alga Hijau) & - & - & 4 & 4 \\
8 & Enteromorpha flexuosa & 3 & - & - & 3 \\
9 & Ulfa Fasciata & 2 & - & - & 2 \\
10 & Boergesenia forbessi & 6 & - & - & 6 \\
11 & Halimeda opuntia & 4 & 3 & - & 3 \\
12 & Halimeda morcoloba & - & 5 & - & 5 \\
13 & Halimeda tuna & 6 & - & - & 6 \\
14 & Dictyosphaeria cavernosa & - & - & 1 & 1 \\
15 & Chaetomorpha spiralis & 5 & - & - & 5 \\
\hline & Phaeophyta (Cokelat) & & & & 7 \\
16 & Dictyota dichotoma & - & 2 & 5 & 8 \\
17 & Padina australis & 5 & 3 & - & 2 \\
18 & Hydroclathrus clathratus & - & 2 & - & 5 \\
19 & Sargassum polycystum & - & 5 & - & 10 \\
20 & Turbinaria ornata & - & 6 & 4 & \\
\hline
\end{tabular}

Tabel 6. Analisis Butiran Substrat pada Lokasi Penelitian

\begin{tabular}{lcccccc}
\hline \multirow{2}{*}{ Partikel } & \multicolumn{2}{c}{ Stasiun 1 } & \multicolumn{2}{c}{ Stasiun 2 } & \multicolumn{2}{c}{ Stasiun 3 } \\
\cline { 2 - 6 } & $\begin{array}{c}\text { Presentase } \\
(\mathbf{\%})\end{array}$ & Kategori & $\begin{array}{c}\text { Presentase } \\
(\mathbf{\%})\end{array}$ & Kategori & $\begin{array}{c}\text { Presentase } \\
(\mathbf{\%})\end{array}$ & Kategori \\
\hline Karang & - & & - & & 100 & \\
\hline $\begin{array}{l}\text { Pecahan } \\
\text { Karang }\end{array}$ & - & & 71,5 & & Karang \\
\hline Kerikil & 0,88 & Pasir & & $\begin{array}{l}\text { Pecahan } \\
\text { karang }\end{array}$ & \\
\hline $\begin{array}{l}\text { Pasir sangat } \\
\text { kasar }\end{array}$ & 14,34 & & 16,52 & & \\
\hline Pasir halus & 77,02 & 8,82 & & \\
\hline
\end{tabular}


Kepadatan makroalga akan semakin tinggi apabila kondisi perairan tempat makroalga tumbuh dalam keadaan baik atau stabil. Hal tersebut didukung oleh penyataan Baso (2018) dalam penelitiannya, tinggi rendahnya kepadatan jenis makroalga dalam suatu perairan dapat dikarenakan oleh kondisi lingkungan perairan itu sendiri. Pernyataan tersebut dipertegas oleh pernyataan Kadi (2017) yang menyatakan bahwa, keberadaan makroalga dipengaruhi oleh interaksi faktor lingkungan fisika-kimiawi suatu perairan.

Berdasarkan hasil analisis yang telah dilakukan, kepadatan makroalga pada setiap stasiun berbeda, kepadatan makroalga yang tertinggi terdapat pada stasiun I yaitu dengan jumlah 32,056 ind $/ \mathrm{m}^{2}$. Tingginya kepadatan makroalga pada stasiun I dan II dikarenakan makroalga lebih menyukai habitat substrat berpasir dan pecahan karang. Hal ini menunjukkan bahwa kondisi perairan di stasiun ini cocok bagi pertumbuhan makroalga. Salah satu faktor yang paling berpengaruh terhadap kehidupan makroalga adalah substrat. Hal ini sesuai dengan pernyataan Palallo (2013), bahwa makroalga yang tumbuh pada tipe substrat yang cenderung sesuai, akan menyebabkan tingkat kepadatan makroalga tersebut semakin tinggi. Sebaliknya makroalga yang tumbuh pada substrat yang cenderung tidak sesuai akan menyebabkan keberadaan makroalga tersebut jauh lebih sedikit. Hal ini diperkuat oleh pernyataan Indriani dan Suminarsi (1991) yang menyatakan bahwa, pada daerah terumbu karang alga umumnya banyak ditemukaan melekat pada batu, potongan kayu, cangkang moluska, potongan karang dan kulit keran.

Rendah kepadatan makroalga pada stasiun III yaitu dengan jumlah 21,667 ind $/ \mathrm{m}^{2}$. Disebabkan oleh kondisi terumbu karang yang masih stabil. Menurut Kadi (2004), bahwa makroalga sangat dipengaruhi oleh pergantian musim dan kondisi substrat paparan terumbu yang stabil dan akan menyebabkan penyebaran jenis rendah serta adanya individu yang dominan.

Perbedaan jumlah kepadatan makroalga pada setiap stasiun dipengaruhi oleh kemampuan adaptasi dari makroalga itu sendiri. Hal ini sesuai dengan pernyataan Ira (2018) yang menyatakan bahwa perbedaan kepadatan makroalga dipengaruhi oleh faktor kondisi lingkungan yang mendukung kemampuan adaptasi masing-masing spesies.
Kepadatan suatu organisme ditentukan oleh kemampuan menyesuaikan diri dengan lingkungan tempat organisme itu hidup. Yudasmara (2011), bahwa perbedaan kepadatan dari masing-masing jenis makroalga sangat dipengaruhi oleh beberapa faktor diantaranya daya reproduksi yang tinggi, kemampuan adaptasi yang lebih berkembang, daya tahan dan lemah terhadap habitat, adanya predator dan penyakit atau keadaan lingkungan yang kurang mendukung.

Selain itu faktor yang mempengaruhi kepadatan jenis makroalga salah satunya adalah faktor kecepatan arus. Kecepatan arus pada lokasi penelitian selama pengamatan tergolong sangat lambat dengan nilai kecepatan 0,08-0,09 m/s. Nilai kecepatan arus di lokasi penelitian kurang baik bagi pertumbuhan makroalnga. Hal ini sesuai dengan penelitian Irwandi $d k k$., (2017) yang menyatakan bahwa, kisaran kecepatan arus 0,07-0,09 $\mathrm{m} / \mathrm{s}$ tergolong rendah dan kurang baik untuk pertumbuhan makroalga karena akan mempengaruhi ketersediaan makanan dan pengendapan (Luning 1990), sedangkan semakin kuat arusnya, pertumbuhan rumput laut akan semakin cepat besar karena difusi nutrien ke dalam sel tanaman semakin banyak sehingga metabolisme dipercepat (Soegianto 1994). Hal ini dipertegas oleh pernyataan Windyastuti (2008) yang menyatakan bahwa, kisaran nilai kecepatan arus yang baik untuk pertumbuhan makroalga yaitu $0,10-0,50 \mathrm{~m} / \mathrm{s}$.

Berdasarkan hasil analisis indeks keanekaragaman (H') makroalga pada lokasi penelitian menunjukkan bahwa nilai keanekaragaman jenis pada stasiun I yaitu 1,910, stasiun II yaitu 2,169 dan stasiun III yaitu 1,121 (Tabel 4). Indeks keanekaragaman di Perairan Wandoka menunjukan nilai keanekaragaman yang sedang. Indeks keanekaragaman sedang disebabkan oleh kondisi lingkungan yang masih cukup stabil dan banyaknya jenis yang didapatkan. Hal ini sesuai dengan pernyataan Odum (1996) yang menyebutkan bahwa nilai $1<\mathrm{H}^{\prime}<3$, artinya keanekaragaman jenis sedang dan daya dukung lingkungan terhadap komunitas cukup baik. Menurut Soegianto (1994), suatu komunitas dikatakan mempunyai keanekaragaman jenis tinggi jika komunitas itu disusun oleh banyak jenis dengan kelimpahan jenis yang sama atau hampir sama. Sebaliknya jika komunitas itu disusun oleh sangat sedikit jenis yang dominan maka keanekaragaman 
jenisnya rendah. Hal ini diperkuat oleh pernyataan Palallo (2013) dalam penelitianya di Pulau Bonebatang dengan nilai indeks keanekaragaman $\left(\mathrm{H}^{\prime}\right)$ yang berkisar 1,31-1,70 termasuk dalam kategori sedang.

Tinggi rendahnya keanekaragaman spesies yang ada disuatu perairan sangat dipegaruhi oleh jumlah spesies itu sendiri, semakin tinggi jumlah spesies maka keanekaragaman semakin tinggi. Hal ini sesuai dengan pernyataan Farito dkk., (2018) yang menyatakan bahwa, perbedaan nilai indeks keanekaragaman makroalga dipengaruhi oleh jumlah individu setiap jenis dan jumlah total seluruh jenis makroalga. Nirwan $d k k$., (2013) yang menyatakan bahwa, semakin sedikit jumlah jenis dan jumlah individu setiap jenis suatu organisme maka nilai indeks keanekaragaman semakin kecil. Hal ini juga diperkuat oleh pernyataan Mangguran (2014), keanekaragaman jenis berkaitan dengan kekayaan jenis dan distribusinya didalam suatu komunitas. Menurut Gumay $d k k$., (2002) yang menyatakan bahwa, nilai keanekaragaman yang kecil menggambarkan sedikitnya jumlah makroalga yang ada di perairan tersebut dan juga menandakan adanya sepesies yang mendominansi.

Selain itu faktor lingkungan yang mempengaruhi keanekaragaman yaitu kedalaman dan kecerahan suatu perairan. Berdasarkan hasil pengukuran kedalam di Perairan Wandoka berkisar antara 1,4-2,7 m dan masih terkena paparan sinar matahari sedangkan hasil pengukuran kecerahan perairan pada setiap stasiun yaitu $100 \%$. Hal ini sesuai dengan pernyataan Wuhlan (2006) yang menyatakan bahwa semakin dalam suatu perairan maka semakin sedikit jumlah spesies yang didapatkan. Hal ini diperkuat oleh pernyataan Ningsi (2006) yang menyatakan bahwa kisaran rata-rata kecerahan yang baik untuk pertumbuhan makroalga yaitu $80-95 \%$. Irwandi $d k k$., (2017) menambahkan dimana kecerahan sangat penting karena erat kaitanya dengan proses fotosintesis.

Berdasarkan hasil analisis indeks keseragaman (E) makroalga yang didapatkan pada lokasi penelitian yaitu pada stasiun I dengan jumlah 0,897 , stasiun II dengan jumlah 0,905 dan stasiun III dengan jumlah 0,626 (Tabel 4). Nilai indeks keseragaman di Perairan wandoka menunjukkan nilai keseragaman populasi besar atau tinggi dengan nilai kisaran E > 0,6 (Odum, 1993). Hal tersebut menunjukan bahwa makroalga yang didapatkan pada lokasi penelitian tidak berbeda jauh antara stasiun I, II dan stasiun III. Hal ini sesuai dengan pernyataan Nurkiama $d k k$., (2015) yang menyatakan bahwa keseragaman yang tinggi mengidentifikasikan bahwa jumlah antara makroalga yang ditemukan tidak berbeda jauh (merata). Hal ini diperkuat oleh pernyataan Setyawan dkk., (2014) yang menyatakan bahwa secara kuantitatif dapat dikatakan komunitas makroalga tidak terdapat dominansi satu jenis. Ini dapat dilihat dari indeks kemerataan.

Makrolaga dapat tumbuh dengan baik karena didukung oleh kondisi perairan yang cukup baik dengan faktor lingkungan seperti suhu, salinitas serta $\mathrm{pH}$. Suhu perairan pada ke tiga stasiun berkisar antara $28-30^{\circ} \mathrm{C}$, salinitas pada ke tiga stasiun diperoleh $30 \mathrm{ppt}$ dan $\mathrm{pH}$ perairan pada ke tiga stasiun yaitu 7 (Tabel 5). Hal ini sesuai dengan pernyatan Faizal $d k k$, (2011) yang menyatakan bahwa suhu normal untuk pertumbuhan makroalga adalah $25-35^{\circ} \mathrm{C}$. Menurut Arfah dan Patty (2014) yang menyatakan bahwa salinitas bekisar $28-34$ ppt dan $\mathrm{pH}$ berkisar $7-8$ merupakan nilai normal untuk pertumbuhan makroalga. Hal ini menunjukan bahwa Perairan Wandoka masih dalam kondisi stabil.

Berdasarkan hasil analisis indeks dominansi pada stasiun I yaitu 0,163 , pada stasiun II yaitu 0,130 dan stasiun III yaitu 0,422 (Tabel 4). Nilai dominansi pada ke tiga stasiun menunjukkan kategori rendah berdasarkan kisaran nilai indeks dominansi Odum (1993) yaitu dengan kisaran $0<\mathrm{D}<1$. Hal ini menunjukkan bahwa Perairan Wandoka tidak ada jenis tertentu yang mendominasi. Hal ini sesuai dengan pernyatan Ferawati $d k k$., (2014) yang menyatakan bahwa suatu komunitas apabila terdapat organisme dengan tingkat dominansi yang rendah maka keanekaragamannya menjadi tinggi. Hal ini sesuai pernyataan Arfah dan Patty (2016) menyatakan bahwa secara umum nampak bahwa nilai keanekaragaman berbanding lurus dengan keseragaman dan berbanding terbalik dengan nilai dominasi. Keanekaragaman jenis makroalga termasuk dalam kategori sedang dan dominasinya rendah.

Indeks dominansi menunjukkan adanya satu atau lebih spesies yang mempunyai peranan yang jauh lebih besar terhadap suatu 
lingkungan perairan. Hal ini sesuai dengan pernyataan Yakin (2009) yang menyatakan bahwa adanya dominansi suatu spesies dalam suatu komunitas disebabkan oleh adanya ketidak merataan jumlah individu dalam spesies. Hal ini diperkuat oleh pernyatan Rasjid (2004) adanya jenis yang mendominasi dapat dipengaruhi oleh persaingan antara tumbuhan yang ada. Persaingan antara tumbuhan maksudnya berkaitan dengan mineral yang diperlukan, jika mineral yang dibutuhkan mendukung maka jenis tersebut akan lebih dominan dan lebih banyak ditemukan.

Frekuensi kemunculan jenis makroalga yang tertinggi didapatkan pada makroalga jenis G. salicornia dengan nilai frekuensi sebesar $11 \%$ hal ini disebabkan oleh kemampuan beradaptasi. G. salicornia yang dapat hidup pada substrat berpasir dan berbatu. Hal ini sesuai dengan pernyataan Mariam $d k k$., (2016) yang menyatakan bahwa $G$. salicornia dapat hidup pada tipe substrat yaitu substrat karang, batu, berpasir, dan di rataan intertidal. Hal ini juga didukung oleh pernyataan Sukiman $d k k$., (2014) yang menyatakan bahwa kelas Rhodopyta banyak ditemukan di wilayah Sekotong. Hal ini disebabkan karena Rhodophyta memiliki kemampuan adaptasi yang lebih luas dari pada makroalga hijau atau cokelat.

Nilai frekuensi terendah terdapat pada makroalga jenis $D$. cavernosa dimana nilai frekuensi kemunculan $1 \%$. Jenis makroalga ini ditemukan pada substrat karang pada Perairan Wandoka. Mariam $d k k$., (2016) yang menyatakan bahwa $D$. cavernosa hidup pada substrat batuan dan patahan karang.

Substrat merupakan salah satu faktor fisik lingkungan yang mempengaruhi pertumbuhan makroalga dan merupakan indikator penentu jenis makroalga disuatu perairan. Berdasarkan hasil penelitian menunjukkan bahwa erat hubungannya antara substrat dan komposisi jenis. Hal ini tergantung bagaimana makroalga dapat beradaptasi dengan kondisi lingkungan tempat hidupnya. Stasiun I dengan kondisi substrat berpasir jenis makroalga yang ditemukan beranekaragam dari kelas Chlorophyta, Phaeophyta dan Rhodophyta. Berdasarkan hasil penelitian kelas Chlorophyta yang paling banyak ditemukan pada lokasi penelitian yaitu dari jenis Halimeda. Hal ini sesuai dengan pernyataan Palallo (2013) yang menyatakan bahwa Chloropyta merupakan kelas terbesar dari semua kelas alga. Hal ini didukung oleh pernyataan Kurniawan (2017) yang menyatakan bahwa Halimeda tumbuh subur pada substrat berpasir. Disebabkan jenis Halimeda tersebut memiliki adaptasi yang luas hampir semua jenis substrat ditemukan dapat tumbuh.

Stasiun II dengan substrat pecahan karang jenis makroalga yang ditemukan juga beranekaragam dari kelas Chlorophyta, Phaeophyta, dan Rhodophyta. Kelas Phaeophyta yang paling banyak ditemukan pada stasiun II. Stasiun III dengan substrat terumbu karang didapatkan jenis yang paling banyak jaga dari kelas Phaeophyta. Hai ini sesuai dengan pernyataan Zulfia $d k k$., (2016) yang menyatakan bahwa kelas Phaeophyta dan Rhodophyta paling banyak dijumpai pada daerah pasang surut. Hal tersebut dikarenakan kedua devisi tersebut memiliki sturktur yang sudah meyerupai tumbuhan tingkat tinggi berupa holdfast. Holdfast adalah struktur seperti akar di dasar alga, seperti sistem akar pada tanaman. Berfungsi untuk jangkar alga di tempat pada substrat dimana ia tumbuh.

\section{Kesimpulan}

Berdasarkan hasil dan pembahasan maka dapat disimpulkan sebagai sebagai berikut:

1. komposisi jenis makroalga yang ditemukan di Perairan Wandoka terdiri dari 20 jenis makroalga diantaranya 7 jenis Rhodophyta, 8 jenis chlorophyta dan 5 jenis Phaeophyta.

2. Kepadatan makroalga yang tertinggi terdapat pada substrat pasir dan terendah terdapat pada substrat terumbu karang.

3. Keanekaragaman jenis masuk dalam kategori sedang, tingkat keseragaman tinggi dan dominansi rendah.

\section{Daftar Pustaka}

Arfah, H. dan Patty, S. I. 2014. Keanekaragaman dan Biommasa Makroalga di Perairan Teluk Kotania, Seram Barat. LIPI. Jakarta.

Ariani, Nurgayah, W., Afu, A. O. L. 2017. Komposisi dan Distribusi Makroalga Berdasarkan Tipe Substrat di Perairan Desa Lalowaru Kecamatan Moramo Utara. Sapa Laut.

Baso, L. F. A. 2018. Struktur Komunitas dan Kepadatan Makroalga pada Terumbu 
Karang Buatan dari Sampah Plastik dengan Kedalaman Berbeda Setelah 1 Tahun Penurunan. Universitas Halu Oleo, Kendari.

Dawes, C. J. 1981. Marine Botany. John Wiley and Sons. University of South Florida. New York.

Fachrul, M. F. 2007. Metode Sapling Bioekologi. Penerbit Bumi Aksara. Jakarta.

Faizal, A., Jompa, J., Nessa, N., Rani, C. 2011. Pemetaan Sebaran Tutupan Makroalga Kaitanya dengan Kualitas Lingkungan di Kepulauan Spermonde, Sulawesi Selatan. Jurusan Ilmu Kelautan: UNHAS.

Farito, Kasim, M. Nur, I. A. 2018. Studi Kepadatan dan Keanekaragaman Makroalga pada Terumbuh Karang Buatan dari Sampah Plastik di Perairan Desa Tanjung Tiram Kecamatan Moramo Utara Kabupaten Konawe Selatan. Jurnal Manajemen Sumber Daya Perairan 3(2): 93-103

Ferawati, E., Widyartini, D.S. dan Isan, I. 2014. Studi Komunitas Rumput Laut pada Berbagai Substrat di Perairan Pantai Permisan Kabupaten Cilacap. Universitas Jenderal Soedirman. Purwokerto.

Gumay, M. H. Suhartono, dan R. Aryawati. 2002. Distribusi dan Kelimpahan Rumput Laut di Pulau Karimun Jawa, Jawa Tengah. J Aseafo, 2: 1-7.

Indriani, H. dan Suminarsih, E. 1991. Budidaya, Pengelolaan dan Pemasaran Rumput Laut. Penebar Swadaya, Jakarta.

Insafitri. 2010. Keanekaragaman, Keseragaman, dan Dominansi Bivalvi di Area Buangan Lumpur Lapindo Muara Sungai Porong. Jurnal Kelautan. 3(1) : 54-59.

Ira. 2018.Struktur Komunitas Makro Alga di Perairan Desa Mata Sulawesi Tenggara. Jurnal Biologi Tropis. 18(1) : 45-56.

Irwandi, Salwiyah, Nurgayah, W. 2017. Struktur Komunitas Makroalga pada Substrat yang berbeda di Perairan Desa Tanjung Tiram Kecamatan Moramo Utara Kabupaten Konawe Selatan Provinsi Sulawesi Tenggara. Jurnal Manajemen Sumber Daya Perairan. Vol. 2(3): 215-224.
Jha, B., Reddy, C. R. K.,Thakur, M.C., Umamaheswara, R. M. 2009. Seaweeds of India. The Diversity and Distribution of Seaweeds of Gujarat Coast.

Kadi, A. 2017. Interaksi Komunitas Makroalga dengan Lingkungan Peraairan Teluk Cerita Pandegelang. Biosfera. Vol. 34(1): 32-38.

Kasim, M. 2016. Kajian Biologi, Ekologi, Pemanfaatan dan Budidaya Makroalga. Penebar Swadaya. Jakarta.

Kurniawan R. 2017. Keanekaragaman Jenis Makroalga di Perairan Laut Desa Teluk Bakau Kabupaten Bintan Kepulauan Riau. Jurusan Ilmu Kelautan. Universitas Maritim Raja Ali Haji Tanjung Pinang. Riau.

Mangguran, A. 2014. Measuring Deaversity. Blackwell Publishing Company. USA.

Mariam, M. P. W., Kepel, C. R., Lumingas, L. J. L. 2016. Inventarisasi Makroalga di Perairan Pulau Mantehage Kecamatan Wori, Kabupaten Minahasa Utara, Provinsi Sulawesi Utara.

Marianingsi, P., Amelia E., Suroto, T. 2013. Invertarisasi dan Identifikasi Makroalga di Perairan Pulau Untung Jawa. Prosiding Semirata FMIPA Universitas Lampung.

Ningsi, D. 2006. Struktur Komunitas Alga Laut Makrobentik di Pantai TNB Jember.

Nirwan, A., Aidah, A. A., Husain. Samawi, F. M. 2013. Struktur Komunitas Alga Koratin Bentuk Percabangan pada Kondisi Perairan yang Berbeda di Pulau Laelae, Bonebatang dan Badi: Jurusan Ilmu Kelautan Universitas Hasanuddin: Makassar.

Nurkiama, L., Muzahar, Idris, F.2015. Keanekaragaman dan Pola Sebaran Makroalga di Perairan Laut Pulau Puncung Desa Malang Rapat Kabupaten Bintan. Jurusan Ilmu Kelautan. FKIP. 15 Hal.

Nurlela, Nurgayah W., Emiyarti. 2019. Struktur Komunitas Makroalga di Perairan Desa Langara Bajo Konawe Kepulauan. Sapa Laut. 4(1): 31-39.

Nyabakken, J. W. 1992. Biologi Laut Suatu Pendekatan Ekologis. PT. Gramedia. Jakarta.

Palallo, A. 2013. Distribusi Makroalga pada Ekosistem Lamun dan Terumbu Karang di Pulau Bonebatang Kecamatan 
Amatan Ujung Tanah, Kelurahan Urahan Barrang Lompo. Universitas Hasanudin Makassar. Makassar

Papalia, S dan Arfah, H. 2013. Produktifitas Biomasa Makroalga di Perairan Pulau Ambalu, Kabupaten Buru Selatan, LIPI. Jakarta

Romimohtarto, K Dan Juwana, S. 1999. Biologi Laut. Ilmu Pengetahuan Tentang Biota Laut. Penerbit Djambatan. Jakarta.

Rosdiana, Nurgayah, W, Ira. Struktur Komunitas Makroalga di Perairan Waworaha Kecamatan Soropia Sapa Laut. Vol. 2(3): 69-77.

Setyobudiandi, I., Soekendarsi, E., Juariah, U., Bahtiar., Hari, H. 2009. Sari Biota Laut Rumput Indonesia Jenis dan Upaya Pemanfaatan. Unhalu Press. Kendari.

Setiawan, D. E. 2006. Struktur Komunitas Alga Laut Makrobentik di Pantai Gelung Kecamatan Panarukan Kabupaten Situbondo Jawa Timur. Jember: FMIPA Universitas Jember.

Soegianto, A. 1994. Ekologi Kuantitatif. Usaha Nasional. Surabaya.

Sukiman, Adibah, M., Sri, P. A., Haliman A., Evy, A. 2014. Keanekaragaman dan Distribusi Spesies Makroalga di Wilayah Sekotong Lombok Barat. Jurnal Penelitian Unram. Vol 18 (2)

Odum, E.P. 1996. Dasar-dasar Ekologi. Edisi ketiga. Gaja Mada Universitas Press. Jogjakarta.

Widyastuti, S. 2008. Pengolahan Pasca Panen Alga Merah Strain Lokal Lombok Menjadi Agar-agar Menggunaan Dua Metode Ekstrasi. Jurnal Penelitian Unram Vol . 14(2): 63-72.

Wulhan, 2006. Komposisi dan Kepadatan Makroalga Berdasarkan Kedalaman pada Keramba Jaring Apung di Perairan Desa Sorue Jaya Kecamatan Soropia Kabupaten Konawe. Universitas Halu Oleo. Kendari.

www. Algabase.org

Yakin, K., Burhanuddin I., Samad W. 2009. Biodiversity of Seaweed and Their Metal Contents from Littoral Zone of South Sulawesi Waters. Universitas Hasanuddin Makassar.

Yudasmara, A. 2011. Analisis Komunitas Makroalga di Perairan Pulau Menjagan Kawasan Taman Nasioal Bali Barat. Disertasi. IPB Bogor.
Zulfia, A. F., Zafi, S. I., Mawaddah, K., Erinda L., Saptasari, M. 2016. Keanekaragaman Makroalga Sekitar Pantai Pancur Alas Purwo Sebagai Media Pelajaran Realia Mahasiswa Calon Guru Biologi di FMIPA, Universitas Negeri Malang. 